\title{
Shooting of Lepers in China
}

The special correspondent of the Morning Post reports that two hundred and fifteen lepers and nine narcotic peddlers, including a young woman, were executed to-day in widely-separated parts of China.

The military authorities shot lepers at Paiyunshan, in Kwangtung Province, despite the protests of the local populace, according to the "China Daily Times," This is the third such butchery in Kwangtung this year. Lu Tselan, an attractive woman peddler, aged 28 , was shot by a firing squad at Hsuchow, in Kiangsu Province, before a large crowd. She attempted to smuggle a large quantity of heroin from Hsuchow to Chengchow. Eight narcotic dealers in Peking were paraded through the streets and executed, bringing the total executions in Peking this year to 30.

The Japan Chronicle somewhat caustically remarks: " Lepers in South China are to have their miseries ended with a rifle bullet. A Canton telegram states that the continued prevalence of leprosy has led the Kwantung authorities to take this drastic measure for the purpose of combatting the spread of the disease. It is a decision which, if persisted in, will finally stamp out leprosy altogether, but like the new " cure" for drug addiction, there is an air of ruthlessness about it that will win China no sympathy. And yet Canton is only putting into practice the suggestions of leading European and American scientists and thinkers. Doomed to certain death, it is better for the patient-and in the case of leprosy certainly better for society-that his 
life be painlessly ended. China's critics, however, will not look on it in that light, and perhaps it is a little difficult to associate the scientist's euthanasia with a military firing party. Only in normal displays of patriotism does the taking of human life cease to shock."

The China Press states that after hearing a report on details of the massacre of from 50 to 60 lepers in Southern Kwangtung on Easter Sunday, the Chinese Medical Association decided yesterday to enter strong protests to the proper authorities in Nanking and Canton.

The officers of the conference were instructed to take immediate steps to urge that suitable penalties be imposed on " the murderers," that steps be taken to protect lepers, and that precautions be taken to prevent the molestations of those undergoing medical treatment.

Dr. J. L. Maxwell, Secretary of the Council on Medical Missions, who is an authority on leprosy, reported on the massacre at the conference session.

"As the sun was rising on Easter Sunday morning from 50 to 60 Christian leper men and women were murdered by soldiers at the leper settlement of the Yeung-kong mission hospital in southern Kwangtung," he said.

"The institution, which is called King's Mothers Village, is located at Yeung-kong (Yang Kiang is Mandarin), in Southern Kwangtung and was founded 20 years ago. The hospital is supported by funds from the Presbyterian Church in the United States and the Chinese Mission to Lepers. Last year the institution had 56 patients.

"The full story may never be known," he continued, "but sufficient details of unquestionable accuracy are to hand allowing us to picture the course of events.

"For over 20 years this settlement has ministered to the needs of some of the lepers in this region under the able supervision of the doctors of the Yeung-kong mission hospital and other friends. During this period the inmates have received regular medical treatment many of them had greatly improved and a number had become quiescent and non-infectious cases.

"Some financial help has been given by the local Chinese community whose attitude has always been friendly and assistance has from time to time been forthcoming from the Chinese Mission to Lepers. Such funds as it has been possible to secure have not, however, been sufficient to meet completely their needs and has been supplemented by begging.

"Some three weeks ago a senior officer of the soldiers in the neighborhood took up a very hostile attitude towards these poor people and threatened to shoot any lepers that were seen about. He sent a message to this effect to the local authorities. A meeting was immediately called to see what could be done and the civil and military authorities were invited to attend. The former did so but none of the latter put in an appearance, so nothing could be done.

"On the Wednesday before the massacre, however, the military 
notified the lepers that all lepers in the settlement would rceive 10 cents a day. It is evident now that this was done to try and get as many as possible into the settlement with a view to killing them off. Each inmate had to sign his name when receiving his 10 cents. This continued on Thursday, Friday and Saturday.

"On Sunday morning early the inmates were called together to receive their money but, as soon as they had assembled, soldiers rushed in, bound them individually, dragged them out of the settlement and shot every one. Two trenches were dug and the bodies of the men thrown into one and those of the women into another, lime thrown over them and the trenches filled up. Of those murdered between 15 and 20 were women and the rest men.

"The soldiers then re-entered the settlement, breaking open everything and stealing what money could be found. They then burned much of the place except the chapel.

"Here it should be made clear, however, that the soldiers, and the soldiers alone, were responsible for this outrage. The local civil authorities took no part in it and have always shown a helpful attitude towards the settlement as far as they were able. Further, it should be emphasized that this outrage was in direct defiance of the Canton civil authorities, who, at the representations made to them more than a year ago, issued instructions which were posted in every town, including Yeung-kong, that molestation of the lepers was to cease. Indeed the attitude of the central authorities in Canton has, of recent years, always been helpful.

"Finally it should be pointed out that no other action could be so certainly followed by an increase of leprosy in the area affected. From now, and it may be for years, every leper will be driven into hiding and no patient with leprosy will dare to come out for treatment or acknowledge his disease. As the most infectious stage of leprosy is an early one, when concealment is easy, it is quite evident that the results of this appalling exhibition of cruelty may be farreaching and lead to a greatly increased spread of the disease."

In view of all this the Chinese Medical Association Conference adopted the following resolutions :

"That the Chinese Medical Association, in session at the Medical Center, Shanghai, has heard with dismay of the premeditated murder of lepers in the Yeung-kong hospital leper settlement and the subsequent looting of the settlement by soldiers. That, apart from the natural abhorrence of such cruelties, this and similar acts, in direct contravention of the orders of the Canton authorities, as expressed in their published injunctions strictly forbidding the molestation of lepers, do more than anything else to spread the disease by driving every leper into hiding.

"And that immediate steps be taken by the officers of this Conference to approach the proper authorities in Nanking and Canton urging that suitable penalties be imposed on the murderers, that steps be taken to protect the lepers, and especially to prevent the molestation of those undergoing medical treatment."

Further action will probably be taken at the Third National Conference on Leprosy which will be held on April 7 th and 8th at the National Medical College, Fenling-chiao. 